\title{
HOMOLOGOUS AND HETEROLOGOUS ANTIBODY RESPONSE OF INFANTS AND CHILDREN TO MULTIPLE INJECTIONS OF A SINGLE STRAIN OF INFLUENZA VIRUS 1,2
}

\author{
By J. J. QUILligAN, JR., ELVA MINUSE, AND THOMAS FRANCIS, JR. \\ (From the Department of Epidemiology and the Virus Laboratory, School of Public Health, \\ University of Michigan, Ann Arbor)
}

(Received for publication March 13, 1948)

It has been shown that repeated inoculation of immune animals $(1,2)$ does not ordinarily result in significant increases in antibody titer to the homologous strain but that when immunity declines a second inoculation may serve to increase the serum antibody titers well above the level reached after a primary infection. In contrast to normal experimental animals, the common experience with man has been that the antibody response to influenza virus reaches its height after a single inoculation of virus and that repeated inoculations within short intervals do not result in higher levels. Moreover, the accumulated data give little evidence of an exaggerated antibody response to a second stimulus administered after an interval of several months when antibody titers may be declining. It has been repeatedly suggested that the difference observed in the behavior of man and experimental animals is related to the fact that the former usually has already acquired antibody as a result of experience with the disease while the latter is a normal, inexperienced individual. In man the antigenic stimulus is presumed to be limited by the presence of antibody previously acquired $(3,4)$.

Early in the studies of the development of antibodies to different strains of influenza virus it was demonstrated in ferrets that repeated inoculations of the PR8 strain could result in the production of antibodies to a strain of swine influenza virus (5). This broadening in the antibody pattern with multiple injections was subsequently noted when rabbits, or mice were employed ( 5 to 8 ).

It was of interest, then, to consider whether infants and young children, who had been sub-

\footnotetext{
1 This investigation was conducted under the auspices of the Commission on Influenza, Army Epidemiological Board, Office of the Surgeon General, United States Army, Washington, D. C.

2 Also aided by United States Public Health Research Grant.
}

jected to little or no exposure to influenza, when given repeated injections of influenza virus vaccine would exhibit a broadening in antibody coverage against antigenically different strains even though the height of response to the homologous strain was little changed. The present report comprises results of a study undertaken to answer this question.

There was no evidence that influenza $\mathrm{A}$ had been prevalent in Michigan since the winter of 1943-44. Hence a group of young human individuals with average age of 3.2 years and largely without antibody to selected strains of influenza virus was chosen for the study.

\section{MATERIALS AND METHODS}

\section{Subjects}

The children were from the Sarah Fisher Home of the House of Providence in Farmington, Michigan. Approximately 90 children were divided into three groups. Their average age was 3.2 years. The age composition of each of the three groups was essentially as follows:

$$
\begin{aligned}
& \text { Age in years No. of children } \\
& 1-1.9 \ldots \ldots \ldots \ldots \ldots \ldots 5 \\
& 2-2.9 \ldots \ldots \ldots \ldots \ldots \ldots \ldots, 7 \\
& 3-3.9 \ldots \ldots \ldots \ldots \ldots \ldots \\
& 4-4.9 \ldots \ldots \ldots \ldots \ldots \ldots .9 \\
& 5-5.9 \ldots \ldots \ldots \ldots \ldots, 3 \\
& \text { Total......... } \overline{31} \text { (average age } 3.2 \text { years) }
\end{aligned}
$$

Children with allergic tendencies were omitted from the study groups. It is worth noting that eggs represented a substantial portion of the diet and any egg sensitization probably would have become readily evident a short time after entering the home. During the course of the study an occasional child missed a scheduled dose of vaccine because of illness, discharge from institution or other reason.

There had been no previous program of vaccination with influenza virus at the home. However, concurrent with the outbreak of type $B$ influenza in the winter of $1945-46$ in this area $(9,10)$ there had been a sharp increase in the number of children with elevations of temperature and upper respiratory disease in the cottages 
where daily temperatures were recorded. There was no evidence of a rise in the rate of acute respiratory disease during the spring and summer of 1946.

\section{Vaccine}

The vaccine was freshly prepared and furnished through the courtesy of Dr. Herald C. Cox of the Lederle Laboratories. It represented allantoic fluid from embryonated eggs infected with the PR8 strain that was concentrated 20 times in a Sharples centrifuge. It contained $0.1 \%$ formalin and merthiolate in a dilution of $1: 2,500$. The protein content, determined by micro-Kjeldahl nitrogen, was $2.0 \mathrm{mg}$. per $\mathrm{ml}$. Before being sent to this laboratory it was tested for hemagglutinating titer using the technic of Hirst and Pickels (11), and showed a titer of hemagglutinins of 2,140.3 Tests done in this laboratory with the Salk method (12) of chicken erythrocyte agglutination resulted in a titer of 10,240 for the same preparation. Using the latter method the preparation when diluted twice gave a titer of 5,120. Further dilution to 1:15 was made and this gave a titer of 640 . Another portion of the same batch of vaccine was diluted 1:72. The titer of agglutinins for chicken erythrocytes was 128 . In the vaccination program $0.5 \mathrm{ml}$. amounts of the above dilutions were given subcutaneously unless indicated otherwise.

\section{Administration of vaccine}

Group I was given a large dose subcutaneously every other week for five doses. Group II was given a small dose subcutaneously every other week for five doses and Group III was given the more dilute preparation every other day for five doses. The schedule for the administration of the vaccine preparations is listed in Table I.

Group I received the first dose of $0.1 \mathrm{ml}$. of the $1: 2$ dilution of vaccine on 8-27-46. A number of severe febrile toxic reactions occurred and the amount was subsequently reduced. On 9-11-46, 9-25-46, 10-8-46 and 10-24-46, the children in this group received $0.5 \mathrm{ml}$. of the $1: 15$ dilution of vaccine; a total of five doses at two-week intervals. Prior to each dose $0.02 \mathrm{ml}$. of the $1: 72$ dilution of vaccine was given intradermally in the left forearm. The children were then observed during the next 30-minute period for the development of local reactions at the site of the skin test. If even minimal erythema was present $0.1 \mathrm{ml}$. of the vaccine was given subcutaneously and the child observed for an additional 30-minute period. No further untoward effects were noted, and the remaining $0.4 \mathrm{ml}$. in the dose was given subcutaneously.

Group II received $0.5 \mathrm{ml}$. of the $1: 72$ dilution of vaccine on 8-28-46, 9-12-46, 9-26-46, 10-9-46 and 10-25-46. Skin tests, as in Group I, were also carried out.

Group III was given vaccine every other day. The first dose given on $8-29-46$ consisted of $0.5 \mathrm{ml}$. of the

8 Throughout the remainder of this report the titer will be expressed as the reciprocal of the final dilution of virus or serum.
TABLE I

Vaccination and bleeding schedule for the three groups of children

\begin{tabular}{|c|c|c|c|}
\hline Group No. & Dosage of vaccine & $\begin{array}{l}\text { Dates of } \\
\text { adminis- } \\
\text { tration }\end{array}$ & $\begin{array}{l}\text { Dates of } \\
\text { bleeding }\end{array}$ \\
\hline $\begin{array}{l}\text { I. Large dose } \\
\text { every other } \\
\text { week-five } \\
\text { times. }\end{array}$ & $\left|\begin{array}{l}0.10 \mathrm{ml} . \text { of } 1: 2^{*} \\
0.50 \mathrm{ml} \text {. of } 1: 15 \ddagger\end{array}\right|$ & $\begin{array}{c}8-27-46 \\
9-11-46 \\
9-25-46 \\
10-8-46 \\
10-24-46\end{array}$ & $\begin{array}{c}8-27-46 \\
9-11-46 \\
10-8-46 \\
11-6-46 \\
4-29-47\end{array}$ \\
\hline $\begin{array}{l}\text { II. Small dose } \\
\text { every other } \\
\text { week-five } \\
\text { times. }\end{array}$ & $0.50 \mathrm{ml}$. of $1: 72$ & $\begin{array}{c}8-28-46 \\
9-12-46 \\
9-26-46 \\
10-9-46 \\
10-25-46\end{array}$ & $\begin{array}{c}8-28-46 \\
9-12-46 \\
10-9-46 \\
11-7-46 \\
4-30-47\end{array}$ \\
\hline $\begin{array}{l}\text { III. Small dose } \\
\text { every other } \\
\text { day-five } \\
\text { times. }\end{array}$ & $\begin{array}{l}0.30 \mathrm{ml} . \text { of } 1: 72 \dagger \\
0.50 \mathrm{ml} \text {. of } 1: 72 \ddagger\end{array}$ & $\begin{array}{l}8-29-46 \\
8-31-46 \\
9-2-46 \\
9-4-46 \\
9-6-46\end{array}$ & $\begin{array}{l}8-29-46 \\
9-21-46 \\
5-2-47\end{array}$ \\
\hline
\end{tabular}

* First dose. † Third dose. $\ddagger$ All other doses.

1:72 dilution. This amount was repeated on 8-31-46. Some reactions occurred approximately six hours after both injections. On 9-2-46 the amount of vaccine was reduced to $0.3 \mathrm{ml}$. and the eight children who had reactions after the first and/or second doses did not receive any vaccine on this date. However, all but one child received the fourth and fifth injections of $0.5 \mathrm{ml}$. on 9-4-46 and 9-6-46. Aiter the fourth dose only one febrile reaction occurred and none after the last injection.

\section{Serological studies}

The schedule for withdrawal of blood specimens in the three groups with the exact dates is summarized in Table I. It can be seen that additional blood samples were obtained approximately six months after the last dose of vaccine. This will be presented in a later report.

The Salk method (12) of determining the agglutination-inhibiting antibodies in the collected sera was used. Four agglutinating units of antigen were mixed with the serially diluted sera. The action of the blood sera in inhibiting the agglutination of four type $A$ strains and two swine strains was measured. The type A strains used were: PR8 (13); Weiss (14); Baum, isolated in New York in 1941; and Olson, isolated in 1943 in Dr. Eaton's laboratory in California. The two strains of swine influenza virus, 1976 and Oti, were obtained from Dr. R. E. Shope. The passage history of the strains used is as follows: PR8-seven ferret, 593 mouse, and 56 egg passages; Weiss-three ferret, 32 mouse, and 41 egg passages; Baum-nine ferret, ten mouse, and 19 egg passages; Olson-seven egg passages. It is not known how many times the swine strains had been passed through swine: 1976 had 38 mouse and 17 egg passages; Oti had 179 mouse and $30 \mathrm{egg}$ passages. All strains of virus were inoculated into ten day old embryonated eggs and the allantoic fluid was removed after incubation for 48 
hours at $35^{\circ} \mathrm{C}$. Passages were maintained until the allantoic fluids showed consistently high agglutination titers of virus with chicken erythrocytes. Then, large pools of allantoic fluid containing virus were prepared and clarified by adsorption and elution from red cells and restored either to the original volume or concentrated ten or 20 times in salt solution (15), after which they were stored for use in the tests. Several preliminary triplicate agglutination tests were carried out with the eluted virus preparations (Table II). The average titer

TABLE II

Average titers of the different strains of virus used
in agglutination-inhibition test

$\begin{array}{lcc}\text { Virus strain } & \text { Aggl. titers* } & \text { Titer used in tests } \\ \text { PR8 } & 2560 & 1: 640 \\ \text { Weiss } & 5120 & 1: 1280 \\ \text { Baum } & 2560 & 1: 640 \\ \text { Olson } & 2560 & 1: 640 \\ \text { Swine 1976 } & 2560 & 1: 640 \\ \text { Swine-Oti } & 2560 & 1: 640\end{array}$

* Done in triplicate on five successive days.

of five different triplicate agglutination tests was used to determine the amount of each virus used in the agglutination-inhibition tests. Pooled erythrocytes were obtained from the same chickens for all tests. A further check on the consistency of the results was made by the use of the same standard pools of sera of high and low titer as controls in each test. All sera from an individual were tested at the same time.

\section{RESULTS}

It was first noted that the prevaccination titers of the individual sera from the three groups followed a definite age pattern when the tests against the PR8 strain were analyzed. Only one of 54 children under four years of age had a serum antibody level greater than 32 (Table III). Conversely, of 22 children, four years of age or older,
TABLE III

Prevaccination agglutination-inhibition titer against the $P R 8$ strain of type $A$ influenza virus in relation to age of children whose sera were tested

\begin{tabular}{|c|c|c|c|}
\hline \multirow{2}{*}{ Age in years } & \multicolumn{2}{|c|}{ Agglutination-inhibition titer } & \multirow{2}{*}{$\begin{array}{c}\text { Total no. } \\
\text { of sera }\end{array}$} \\
\hline & 32 or less & 64 or greater & \\
\hline $\begin{array}{ll}1-1 & 11 / 12 \\
2-2 & 11 / 12 \\
3-3 & 11 / 12 \\
4-4 & 11 / 12 \\
5-6 & \end{array}$ & $\begin{array}{r}9 \\
21 \\
24 \\
15 \\
7\end{array}$ & $\begin{array}{r}0 \\
0 \\
1 \\
11 \\
1\end{array}$ & $\begin{array}{r}9 \\
21 \\
25 \\
26 \\
8\end{array}$ \\
\hline
\end{tabular}

12 had initial titers of 64 or greater. This would suggest that the majority of the group had had no appreciable previous experience with influenza virus. This lack of experience was more evident in the individuals under four years of age, and corresponded to the epidemiological information that influenza $\mathrm{A}$ had not been prevalent in this area for at least three years.

The data were then analyzed as follows: 1 ) modified mean antibody titers (10) for each group (Table IV) ; 2) charts showing the distribution of antibody titers against each test strain of virus in each group (Figures 1 to 3 ) ; 3) modified mean titers of selected individuals in each group (the basis for the selection was those individuals who had all the scheduled doses of vaccine and bleedings and whose prevaccination titers were less than 32; these latter children were thought to represent individuals with little or no experience with influenza viruses [Table V]); and 4) the mean titers in each group measured against the PR8 strain and tabulated according to age (Table VI).

TABLE IV

The modified arithmetic mean titers of the three groups expressed as the reciprocals of the highest final dilution of serum causing inhibition of agglutination

\begin{tabular}{|c|c|c|c|c|c|c|c|c|c|c|}
\hline \multirow{2}{*}{ Strain } & \multicolumn{4}{|c|}{$\begin{array}{c}\text { Group I } \\
\text { (31 individuals) }\end{array}$} & \multicolumn{4}{|c|}{$\begin{array}{c}\text { Group II } \\
\text { (28 individuals) }\end{array}$} & \multicolumn{2}{|c|}{$\begin{array}{l}\text { Group III } \\
\text { (31 individuals) }\end{array}$} \\
\hline & $\begin{array}{l}\text { Pre- } \\
\text { vacc. }\end{array}$ & $\underset{\text { bleeding }}{2 n d}$ & $\begin{array}{l}\text { 3rd } \\
\text { bleeding }\end{array}$ & $\begin{array}{l}\text { 4th } \\
\text { bleeding }\end{array}$ & $\begin{array}{l}\text { Pre- } \\
\text { vacc. }\end{array}$ & $\underset{\text { bleeding }}{2 n d}$ & $\begin{array}{c}\text { 3rd } \\
\text { bleeding }\end{array}$ & $\begin{array}{l}\text { 4th } \\
\text { bleeding }\end{array}$ & $\begin{array}{l}\text { Pre- } \\
\text { vacc. }\end{array}$ & $\underset{\text { bleeding }}{2 n d}$ \\
\hline $\begin{array}{c}\text { Type A } \\
\text { PR8 } \\
\text { Weiss } \\
\text { Baum } \\
\text { Olson }\end{array}$ & $\begin{array}{r}<32 \\
32 \\
174 \\
<32\end{array}$ & $\begin{array}{r}716 \\
625 \\
1126 \\
371\end{array}$ & $\begin{array}{r}1126 \\
1024 \\
1536 \\
417\end{array}$ & $\begin{array}{r}1024 \\
952 \\
1423 \\
371\end{array}$ & $\begin{array}{r}<32 \\
34 \\
200 \\
40\end{array}$ & $\begin{array}{l}128 \\
247 \\
435 \\
128\end{array}$ & $\begin{array}{l}409 \\
445 \\
819 \\
192\end{array}$ & $\begin{array}{l}338 \\
451 \\
435 \\
235\end{array}$ & $\begin{array}{r}<32 \\
<32 \\
193 \\
<32\end{array}$ & $\begin{array}{r}666 \\
742 \\
1188 \\
256\end{array}$ \\
\hline $\begin{array}{c}\text { Swine } \\
1976 \\
\text { Oti }\end{array}$ & $\begin{array}{l}<32 \\
<32\end{array}$ & $\begin{array}{r}54 \\
128\end{array}$ & $\begin{array}{r}43 \\
119\end{array}$ & $\begin{array}{r}32 \\
113\end{array}$ & $\begin{array}{l}<32 \\
<32\end{array}$ & $\begin{array}{r}<32 \\
41\end{array}$ & $\begin{array}{r}<32 \\
51\end{array}$ & $\begin{array}{r}<32 \\
51\end{array}$ & $\begin{array}{l}<32 \\
<32\end{array}$ & $\begin{array}{l}38 \\
78\end{array}$ \\
\hline
\end{tabular}


TABLE $V$

The modified arithmetic mean titers of the sera of individuals in the three groups with (a) prevaccination titer of $<32$, (b) all the scheduled doses of vaccine and (c) all the scheduled bleedings

\begin{tabular}{|c|c|c|c|c|c|c|c|c|c|c|}
\hline \multirow{2}{*}{ Strain } & \multicolumn{4}{|c|}{$\begin{array}{l}\text { Group I } \\
\text { (19 individuals) }\end{array}$} & \multicolumn{4}{|c|}{$\begin{array}{c}\text { Group II } \\
\text { (14 individuals) }\end{array}$} & \multicolumn{2}{|c|}{$\begin{array}{c}\text { Group III } \\
\text { (19 individuals) }\end{array}$} \\
\hline & $\begin{array}{l}\text { Pre- } \\
\text { vacc. }\end{array}$ & $\begin{array}{l}\text { 2nd } \\
\text { bleeding }\end{array}$ & $\begin{array}{c}\text { 3rd } \\
\text { bleeding }\end{array}$ & $\begin{array}{c}\text { 4th } \\
\text { bleeding }\end{array}$ & $\begin{array}{l}\text { Pre- } \\
\text { vacc. }\end{array}$ & $\begin{array}{c}\text { 2nd } \\
\text { bleeding }\end{array}$ & $\begin{array}{c}\text { 3rd } \\
\text { bleeding }\end{array}$ & $\begin{array}{l}\text { 4th } \\
\text { bleeding }\end{array}$ & $\begin{array}{l}\text { Pre- } \\
\text { vacc. }\end{array}$ & $\begin{array}{l}\text { 2nd } \\
\text { bleeding }\end{array}$ \\
\hline $\begin{array}{c}\text { Type } A \\
\text { PR8 } \\
\text { Weiss } \\
\text { Olson }\end{array}$ & $\begin{array}{l}<32 \\
<32 \\
<32\end{array}$ & $\begin{array}{l}417 \\
221 \\
116\end{array}$ & $\begin{array}{l}835 \\
579 \\
179\end{array}$ & $\begin{array}{l}850 \\
612 \\
173\end{array}$ & $\begin{array}{l}<32 \\
<32 \\
<32\end{array}$ & $\begin{array}{r}100 \\
86 \\
37\end{array}$ & $\begin{array}{r}256 \\
163 \\
64\end{array}$ & $\begin{array}{r}230 \\
197 \\
64\end{array}$ & $\begin{array}{l}<32 \\
<32 \\
<32\end{array}$ & $\begin{array}{l}512 \\
256 \\
170\end{array}$ \\
\hline
\end{tabular}

In calculating the means all sera with titers of less than 32 were assigned the value of 16 . This reduced the mean prevaccination titers and masked those individuals in the groups who had high initial titers. However, these latter sera are demonstrated in the figures showing the distribution of titers in the three groups. Also there are differences in the numbers of individuals who are included in some of the tables. This is occasioned in one instance by the fact that accurate ages were not obtainable; consequently they could not be assigned properly in the tables where age is an important factor. Some sera became contaminated and could not be titrated. The prevaccination titers against the Baum strain were so high, owing to non-specific inhibition, that the results with that antigen were not included in the selected data. Such factors contribute to the slight variations in tabulated data.

The findings summarized in the tables demonstrate that repeated inoculations within limited time intervals, regardless of dosage, resulted in cumulative increases in antibody titer (Table IV and Figures 1 to 3 ). This fact is not in keeping with effects commonly noted in adult humans, but approaches more that observed in experimental animals. Whether or not these differences are significant can not be definitely stated when the data are viewed only in Table IV where the mean titers of the entire groups are presented. However, as seen in Table $\mathrm{V}$ where the mean titers of selected groups are given, the differences follow the same trend observed in Table IV but are more pronounced. Further analysis, using age as a basis for grouping, shows that when subsequent injections of vaccine are administered homologous antibody levels in the children of Group I under four years of age continue to rise beyond the level reached after a single injection. In the children over four, in which some antibody is originally measurable, the maximal titer is observed after the first dose, strongly indicating an accelerated response. These older children were more likely to have had previous experience with influenza. In Group II, where smaller amounts of virus were given, a continued rise was noted in children of both age groups.

The distribution of antibody titers, presented in the three figures shows with each subsequent bleeding a more pronounced grouping effect. The

TABLE VI

Mean titers in the three groups measured against PR8 strain and tabulated according to age

\begin{tabular}{|c|c|c|c|c|c|c|c|c|c|c|}
\hline & \multicolumn{4}{|c|}{$\begin{array}{l}\text { Group I } \\
\text { Large dose every other week } \times 5\end{array}$} & \multicolumn{4}{|c|}{$\begin{array}{c}\text { Group II } \\
\text { Small dose every other week } \times 5\end{array}$} & \multicolumn{2}{|c|}{$\begin{array}{c}\text { Group III } \\
\text { Small dose every } \\
\text { other day } \times 55\end{array}$} \\
\hline & $\begin{array}{l}\text { Pre- } \\
\text { vacc. }\end{array}$ & $\begin{array}{l}\text { 2nd } \\
\text { bleeding }\end{array}$ & $\begin{array}{c}\text { 3rd } \\
\text { bleeding }\end{array}$ & $\begin{array}{l}\text { 4th } \\
\text { bleeding }\end{array}$ & $\begin{array}{l}\text { Pre- } \\
\text { vacc. }\end{array}$ & $\begin{array}{c}\text { 2nd } \\
\text { bleeding }\end{array}$ & $\begin{array}{c}\text { 3rd } \\
\text { bleeding }\end{array}$ & $\begin{array}{c}\text { 4th } \\
\text { bleeding }\end{array}$ & $\begin{array}{l}\text { Pre- } \\
\text { vacc. }\end{array}$ & $\underset{\text { bleeding }}{\text { 2nd }}$ \\
\hline Under 4 yrs. & $\begin{array}{l}<32 \\
(18)^{*}\end{array}$ & $\begin{array}{l}256 \\
(18)\end{array}$ & $\begin{array}{l}1024 \\
(18)\end{array}$ & $\begin{array}{l}1024 \\
(18)\end{array}$ & $\begin{array}{l}<32 \\
(17)\end{array}$ & $\begin{array}{r}92 \\
(17)\end{array}$ & $\begin{array}{l}409 \\
(17)\end{array}$ & $\begin{array}{l}333 \\
(14)\end{array}$ & $\begin{array}{l}<32 \\
(18)\end{array}$ & $\begin{array}{c}512 \\
(18)\end{array}$ \\
\hline 4 years or older & $\begin{array}{r}32 \\
(12)\end{array}$ & $\begin{array}{l}1792 \\
(12)\end{array}$ & $\begin{array}{l}1536 \\
(12)\end{array}$ & $\begin{array}{l}1024 \\
(12)\end{array}$ & $\begin{array}{l}38 \\
(11)\end{array}$ & $\begin{array}{l}128 \\
(11)\end{array}$ & $\begin{array}{l}409 \\
(10)\end{array}$ & $\begin{array}{l}435 \\
(11)\end{array}$ & $\begin{array}{r}38 \\
(11)\end{array}$ & $\begin{array}{l}892 \\
(11)\end{array}$ \\
\hline
\end{tabular}

\footnotetext{
* The numbers in parentheses represent number of individuals from which the means were calculated.
} 
high titers fell somewhat, and the lower titers were elevated. The grouping tendency noted above has been reported before (2). However, the fact that repeated injections of vaccine most frequently affected titers of low value was not pointed out. The most pronounced demonstration of this convergence effect can be seen in the Group I sera in Figure 1.

The titers reached against the heterologous type A strains largely followed the same pattern of development as observed with the homologous strain. Moreover, the antibody response appeared to diminish as the antigenic relationship of the heterologous strains to the PR8 strain receded. The titers obtained against swine virus were not impressive and measurements of the sera against swine strains are not included in the selected group listed in Table V. The quantitative aspects
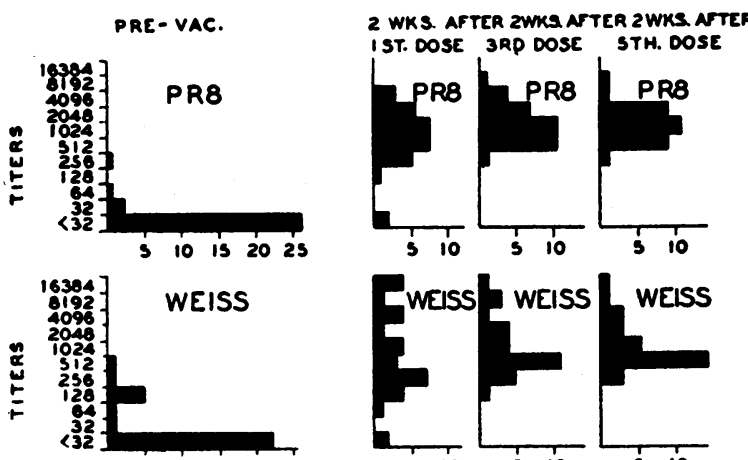

10 is 2025
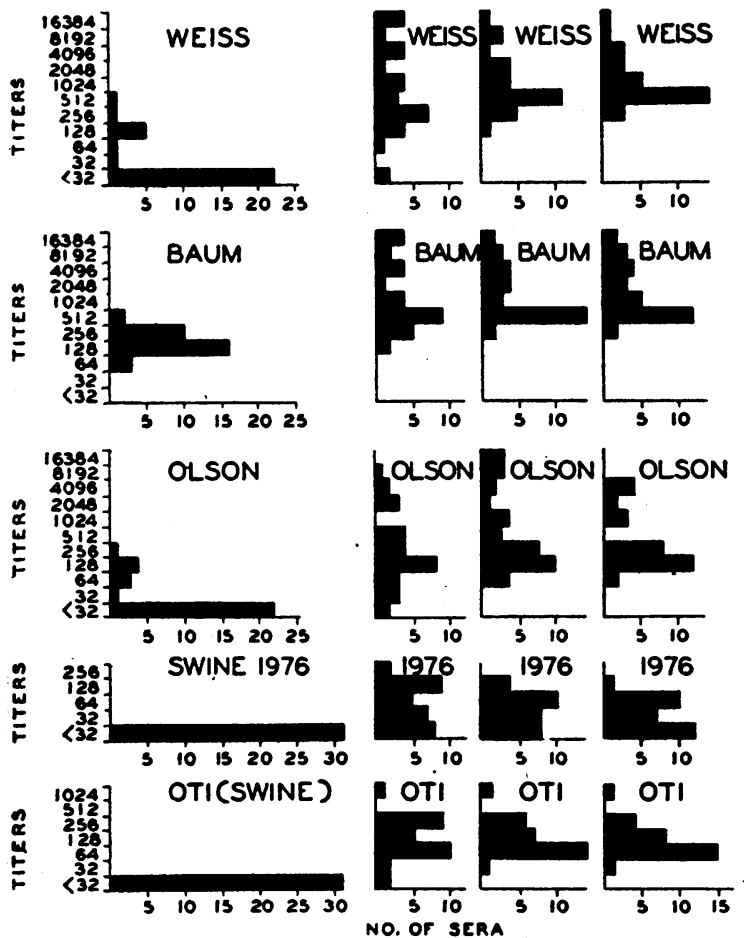

Fig. 1. Distribution of Serum Titrations in Group I against Test Strains
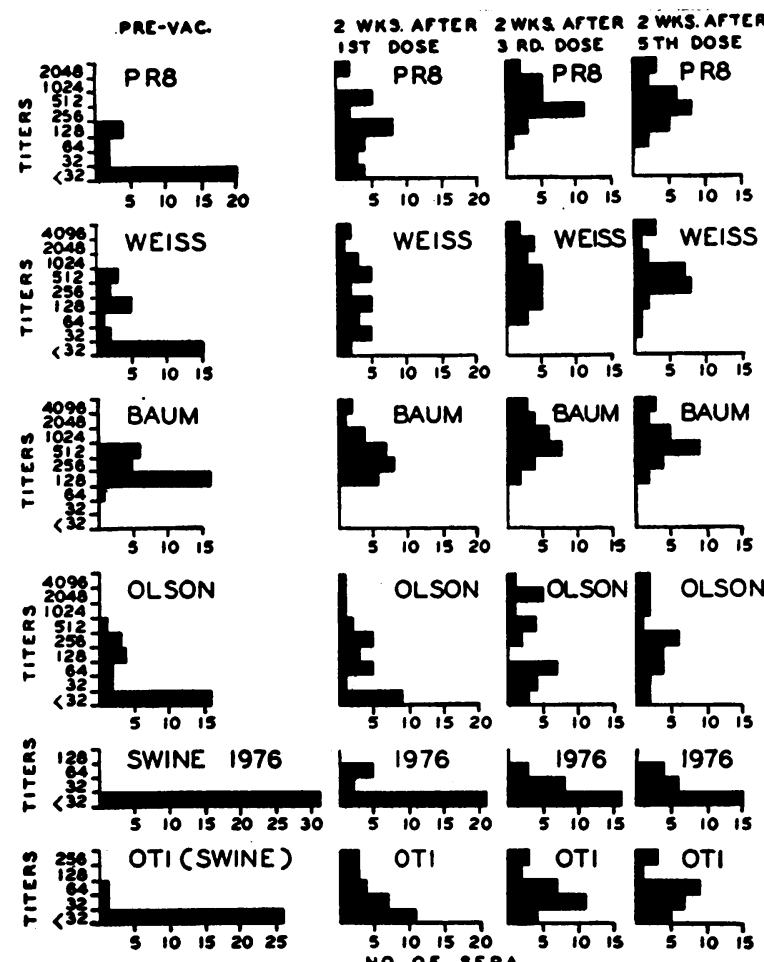

Fig. 2. Distribution of Serum Titrations in Group II against Test Strains

of the antibody responses to the heterologous as well as to the homologous strain are related to dosage (Table IV).

In Group III small doses given every other day for five days resulted in higher titers than in Group II where the same dose was given at twoweek intervals. The mean titers for the former are quite similar to those in Group I after the first dose. The amounts of inactivated virus given in the first dose to Group I and in the five doses to Group III are roughly $5: 3$. So the use of $3 / 5$ as much vaccine given in repeated small doses resulted in as good a response as the use of a single large injection, and with the latter reactions were more frequent. It appears that maximal response with minimum reaction lies somewhere between the programs of Groups I and III.

\section{DISCUSSION}

The present data obtained in groups of infants and young children show that: $(a)$ with a single large dose of influenza virus vaccine the mean antibody titer to the homologous strain was significantly increased; $(b)$ two further injections of 
vaccine resulted in cumulative increases in mean antibody titer; $(c)$ this finding was most evident in children between the ages of one and three and a half years; and $(d)$ where the effect was measurable the use of more than three doses contributed no significant advantages to antibody production.

The above results for the homologous strain were paralleled by the other type A strains tested. The efficiency of multiple injections of the PR8 strain in inducing antibody response to heterologous strains was fairly good with other type A strains and the degree of response appeared to vary with the test strain. Antibody response against two swine strains was meager. However, higher mean levels of antibody to all the strains studied were associated with multiple injections of the PR8 strain except in the children of four years or more who received the large doses; in these instances, the complete effect was obtained with one injection.

Other reports of the antibody response to influenza virus vaccine $(3,16$ to 21$)$ have indicated that maximum titers occur with a single injection of vaccine and that further injections did not increase the height of the titer. However, most of these studies were conducted in older subjects.
It should be pointed out that the interval between the second and third bleedings in Group I was 27 days and that the third bleeding was six weeks after the first dose of vaccine. It is possible that the results obtained in the third bleeding represent continued rise associated with stimulating effect caused by the initial injection. In some individuals, however, no increase in titer was observed two weeks after the first dose suggesting that the subsequent rise in their titers was related to the additional inoculations. This effect of delayed rising of titers was noted more strikingly in Group II. Nevertheless, the data here do not permit a precise conclusion. Further investigation of the time relation of antibody formation in infants and children must be done to clarify this point. The rises in titer against the heterologous type A strains can be postulated as being due to common antigenic characteristics.

The close agreement in mean response of all groups when tested against the PR8 and Weiss strains points to the use of only one of these strains in a vaccine. Recent experience with an outbreak of type A influenza virus infection in the late winter and spring of 1947 (22 to 24) indicates that the PR8 and Weiss strains did not have antigenic characteristics sufficiently broad to

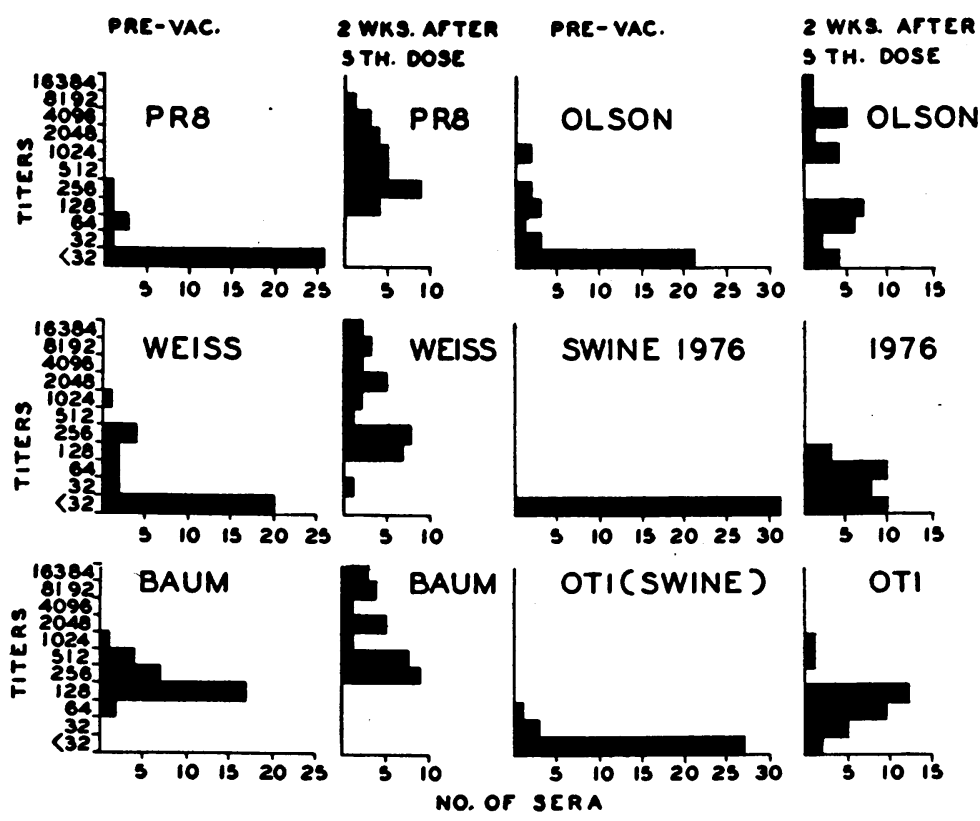

Fig. 3. Distribution of Serum Titrations in Group III against Test Stranes 
stimulate the formation of antibodies against the new strains when a single subcutaneous injection of vaccine was given. Accordingly, the sera of the selected members from Group I were tested against a strain of type $A$ virus isolated in the early 1947 epidemic (Rhodes). Sera from five of the 19 individuals tested had no rise in antibodies between the prevaccination bleeding and the bleeding taken two weeks after the last dose; four had two-fold rises, and 10 had four-fold or greater rises in titer. However, the highest titers reached wete only 512 in four instances. The remainder were 256 or less. Thus repeated vaccinations with the PR8 strain did result in the development of antibodies to the 1947 strain in some of the children.

Other than antigenic specificity, the relation of dose, number of injections, and interval between injections requires some further consideration. It is apparent, from the presented data, that maximal antibody response in children does not always occur with a single injection of vaccine. Despite the fact that a maximal dose, in terms of reactions to the vaccine, was given to the children in Group I, subsequent injections caused a further elevation in titer. This finding was most pronounced in the children under four years of age (Table VI). The amount of vaccine in the first dose was roughly equivalent to $1 \mathrm{ml}$. of infected allantoic fluid. The later injections approximated $0.65 \mathrm{ml}$. of allantoic fluid. With two more injections of the latter amount significant rises occurred in the mean titers against all type A strains tested. Decreasing the dosage to a concentration equivalent to $0.15 \mathrm{ml}$. of infected allantoic fluid, as in Groups II and III, gave lower mean antibody titers. However, using such a small dose the antibody response was greater than anticipated. The results of the Group III study, where the small amount of vaccine was given every other day for five days, showed a better mean titer than when given over the longer period of time as in Group II. As noted earlier the probable optimal dose and interval between doses lies somewhere between the effects noted in Groups I and III, also the use of more than three injections of vaccine did not contribute any significant changes. A reasonable schedule would seem to be the use of three injections of the equivalent of $0.3 \mathrm{ml}$. of infected unconcentrated allantoic fluid spaced at weekly intervals. The use of concentrated material in infants and young children is not advisable unless the vaccine preparation is diluted prior to use.

\section{SUMMARY}

Multiple subcutaneous injections in children, whose average age was 3.2 years, of.an influenza virus vaccine containing the type A PR8 strain, gave greater rises in mean titer of erythrocyte agglutination-inhibiting antibody against the homologous strain than did a single injection of the same virus preparation. In children of four years of age or older, who were living at the time of the last previous epidemic of influenza $A$ in the area, the maximal response was obtained after a single large dose. Rises in titer to three other type A strains tested also occurred. Rises in titer to two strains of swine influenza virus were less pronounced. The height of antibody response to the heterologous strains was apparently influenced by the intimacy of their antigenic relationship to the PR8 strain and was not progressively enhanced as the administration of vaccine was continued beyond three doses.

The significance of the antigenic variation of strains, dosage, and schedule of injections of influenza virus vaccine in children is discussed.

\section{ACKNOWLEDGMENTS}

The authors wish to express their thanks to the following for their gracious cooperation: Miss Annette Zipple of the Virus Laboratory; Sisters Remie and Eugenie of the House of Providence, Sarah Fisher Home, Farmington, Michigan; Dr. Sarah Schooten, attending physician of the Home, from Detroit, Michigan; and Drs. G. Weick, F. R. Reardon, Bruce Graham, and Aaron Stern of the Department of Pediatrics, University of Michigan Medical School, Ann Arbor, Michigan.

\section{BIBLIOGRAPHY}

1. Francis, T., Jr., Quantitative relationships between the immunizing dose of epidemic influenza virus and the resultant immunity. J. Exper. Med., 1939, 69, 283.

2. McLean, I. W., Jr., Beard, D., Taylor, A. R., Sharp, D. G., and Beard, J. W., Relation of antibody response in swine to dose of the swine influenza virus inactivated with formalin and with ultraviolet light. J. Immunol., 1945, 51, 65.

3. Beveridge, W. I. B., Lack of increase in antibody after second injection of influenza virus in man. Australian J. Exper. Biol. \& M. Sc., 1944, 22, 301. 
4. Beveridge, W. I. B., Stone, J. D., and Lind, P. E., Suppression of antigenicity of influenza virus by admixture with homologous antiserum. Australian J. Exper. Biol. \& M. Sc., 1944, 22, 307.

5. Francis, T., Jr., and Shope, R. E., Neutralization tests with sera of convalescent or immunized animals and the viruses of swine and human influenza. J. Exper. Med., 1936, 63, 645.

6. Magill, T. P., and Francis, T., Jr., Antigenic differences in strains of epidemic influenza virus. I. Cross-neutralization tests in mice. Brit. J. Exper. Path., 1938, 19, 273.

7. Francis, T., Jr., and Magill, T. P., Antigenic differences in strains of epidemic influenza virus. II. Cross-immunization tests in mice. Brit. J. Exper. Path., 1938, 19, 284.

8. Eaton, M. D., and Pearson, H. E., Quantitative aspects of homologous and heterologous active immunity to strains of the virus of epidemic influenza. J. Exper. Med., 1940, 72, 635.

9. Francis, T., Jr., Salk, J. E., and Brace, W. M., The protective effect of vaccination against epidemic influenza B. J. A. M. A., 1946, 131, 275.

10. Quilligan, J. J., Jr., and Francis T., Jr., Serological response to intranasal administration of inactive influenza virus in children. J. Clin. Invest., 1947, 26, 1079.

11. Hirst, G. K., and Pickels, E. G., A method for the titration of influenza hemagglutinins and influenza antibodies with the aid of a photoelectric densitometer. J. Immunol., 1942, 45, 273.

12. Salk, J. E., A simplified procedure for titrating hemagglutinating capacity of influenza virus and the corresponding antibody. J. Immunol., 1944, 49, 87.

13. Magill, T. P., and Francis, T., Jr., Antigenic differences in strains of human influenza virus. Proc. Soc. Exper. Biol. \& Med., 1936, 35, 463.

14. Salk, J. E., Menke, W. J., and Francis, T., Jr., Identification of influenza virus type $A$ in current out- break of respiratory disease. J. A. M. A., 1944, 124, 93.

15. Francis, T., Jr., and Salk, J. E., A simplified procedure for the concentration and purification of influenza virus. Science, 1942, 96, 499.

16. Francis, T., Jr., and Magill, T. P., The antibody response of human subjects vaccinated with the virus of human influenza. J. Exper. Med., 1937, 65, 251.

17. Stokes, J., Jr., Chenoweth, A. D., Waltz, A. D., Gladen, R. G., and Shaw, D., Results of immunization by means of active virus of human influenza. J. Clin. Invest., 1937, 16, 237.

18. Stuart-Harris, C. H., Andrews, C. H., and Smith, W., with Chalmers, D. K. M., Cowen, E. G. H., and Hughes, D. L., A study of epidemic influenza: with special reference to the $1936-7$ epidemic. Medical Research Council, Special Report Series, No. 228, 1938.

19. Hare, R., Morgan, J., Jackson, J., and Stamatis, D. M., Immunization against influenza A. Canad. J. Pub. Health, 1943, 34, 353.

20. Henle, W., Henle, G., and Stokes, J., Jr., Demonstration of the efficacy of vaccination against influenza type $A$ by experimental infection of human beings. J. Immunol., 1943, 46, 163.

21. Henle, W., Henle, G., Hampil, B., Maris, E. P., and Stokes, J., Jr., Experiments on vaccination of human beings against epidemic influenza. J. Immunol,. 1946, 53, 75.

22. Francis, T., Jr., Salk, J. E., and Quilligan, J. J., Jr., Experience with vaccination against influenza in the spring of 1947. Am. J. Pub. Health, 1947, 37, 1013.

23. Smadel, J. E., Research in virus diseases. Bull. U. S. Army M. Dept., 1947, 7, 795.

24. Sigel, M. M., Shaffer, F. W., and Henle, W., Epidemic of influenza $A$ among recently vaccinated population: isolation of new strain of influenza $A$ virus. J. Bact., 1947, 54, 277. 